\title{
Measuring language attitudes. The case of Trasianka in Belarus
}

\author{
Natallia Sender (Frankfurt/Oder)
}

\begin{abstract}
In contemporary Belarus there are currently two languages being predominantly used: Russian and Belarusian. Besides dialects and other varieties there is to be found a variety called Trasianka, which is widespread throughout the country. Trasianka can be considered as a variety built of elements from other varieties in Belarus, but mainly from Russian and Belarusian. Originally the term Trasianka stems from agriculture describing a 'mixed fodder of poor quality'. Language attitudes towards this variety have hardly been examined thus far. In a recent study based on the matched-guise technique, 227 Belarusian adolescents listened to and evaluated a female speaker reading the same text in Russian, Belarusian and Trasianka. When the speaker used Trasianka, she was given low ratings by test participants in matters of socio-structural issues such as profession and education. Regarding competence, the test participants assumed that the Trasianka speaker was less qualified, as shown by answers to a question on competencies in foreign languages. Finally, the test participants were more reluctant to accept the Trasianka speaker as a neighbor. With this responsiveness, they performed a bigger social distance. By these findings, there is ample reason to conclude that there are negative attitudes existing amongst today's population in Belarus regarding speakers of Trasianka.
\end{abstract}

\section{$1 \quad$ Introduction}

When looking at the contemporary use of East Slavic varieties in Belarus the Russian language seems to be dominant in society at first blush. Russian can be found in state media, in the political area and in the economy. A closer look, however, reveals that the usage of Russian by people from Belarus often contains mistakes. The cause of this deviation from the Russian standard language is often a mixing of Russian with the second standard language of the country - Belarusian - or vice versa, and some varieties. The result of this mixing is a variety which is commonly called Trasianka. This language mixing can be found almost everywhere in modern-day Belarus - even in literature, comics and broadcasts.

An oral statement of a 70-year-old resident from the Gomel region gives a good impression as to the characteristics of Trasianka. On the Belarusian broadcaster Radio Stalica ${ }^{1}$, he uttered a sentence during a discussion on Chernobyl in 2009 that can be translated as 'And then they will learn about the truth'. A translation in standard Russian (characters in italics) in SAMPA would be " $i$ v"ot an"'i tagd"a uzn"ajut pr"avdu". In standard Belarusian (bold characters), this sentence would be "i v"os' jan"1 tad"1 dav'"jEdajutsa pr"aŭdu". What he actually said was "i $v^{\prime \prime} o t \quad a n^{\prime \prime} i$ tagd"a uzn"ajuts' pra"ŭdu" (with the word $i$ being an identical word in Russian and Belarusian). ${ }^{2}$ This example shows one buildingpattern of Trasianka as a result of code-mixing between Russian and Belarusian. Being a product of this code-mixing, Trasianka can easily be understood and recognized by people

\footnotetext{
1 The station is available online at www.tvr.by/liveair/radiostol.asx, accessed August 6, 2013.

2 This example is taken from Sender (2008: 58).
} 
who speak Russian and/or Belarusian as something not pure. However, there exists no fixed system of rules in Trasianka. Rather, its intrapersonal and interpersonal usage is characterized by a combination of individual mixing of standard languages and varieties. This combination can differ from speaker to speaker, and even in the speech of one speaker at different times (cf. Sender 2008: 17, 20).

Research on the characterization and the building-processes of Trasianka has only just begun. It is only since the 1990s that linguistic research has discovered that language use in Belarus involves more than just Russian, Belarusian and some dialects. Research on sociolinguistic questions like reputation and the treatment of Trasianka speakers is therefore still at the beginning as well. Given the fact that speakers of Trasianka use the Russian and/or Belarusian standard language only partially - these standard languages are typically used in leading positions of society - it could be expected that Trasianka, as the result of an imperfect ability to speak standard Russian or Belarusian, is regarded as the specific language of people with no higher education and working in low-profile jobs. Therefore, for the case of Belarus, the question arises whether the speakers of Trasianka are somehow confronted with certain prejudgments.

\section{$2 \quad$ Trasianka and its origin}

Current research states that the etymological meaning of the term Trasianka originates from the agriculture sphere. Trasianka was understood in this realm as a low-quality mixture of feed for cattle. Not only the term Trasianka, but also the stigmatization of this mixture in the agricultural sphere, was later assigned to the mixed language of Belarusian and Russian. Current discussions surrounding Trasianka in everyday life as well as in science still contain this low quality-connotation. It is not yet determined at which point in history this term was used for the first time to refer to this variety. ${ }^{3}$ However, the long-lasting existence of the variety Trasianka can at least be traced back to prose literature published at the end of the $19^{\text {th }}$ and the beginning of the $20^{\text {th }}$ century. Trasianka can be found inter alia in DuninMarcinkevičs (2001) opus Pinskaja šljahta ${ }^{4}$ (The nobility of Pinsk) from 1866 as well as in the opus Tutejšyja (The locals) of Kupala (2006) published first in 1922. The usage of Trasianka in these texts leads to the only possible conclusion that this mixture must have already existed in those years. By this written evidence and the time of its publishing, these prose texts deliver convincing arguments that the development of Trasianka is linked to the Russification of Belarus in the decades before. Taking this into account, Mečkovskaja reasons that Trasianka must have emerged in connection with the Russification of the people of Belarus after the incorporation of Belarusian territory into the Russian Empire during the first two partitions of the Rzeczpospolita in 1772 and 1793. ${ }^{5}$ But these first attestations of Trasianka in the $19^{\text {th }}$ century do not say anything yet about the intensity of its usage among the population in the centuries following. So other authors have focused their studies on the analysis of the time period when Trasianka started to become widely used in society. From this perspective

\footnotetext{
3 While Belarusian linguist Cychun (2000) did not find an exact specification for the time of the emergence of this term, Belarusian politician Paznjak claims the first usage of the term Trasianka for himself. Paznjak declared that he named the Belarusian-Russian Pidgin as Trasianka in 1988. See his statement on January 11, 2001 in the newspaper Narodnaja Volja, cited in Tavarystva belaruskaj movy: https://web.archive.org/ web/20081120163307/http://tbm.org.by/tbm_old/bel/mova/2001/11.htm, accessed January 23, 2011.

4 In his work Dunin-Marcinkevič (2001: 64) writes about a person called Krjučkov who tries to announce decrees on Russian. Krjučkov attempts however result in Trasianka since he is obviously a Belarusian speaking person who is not able to speak adequately in Russian.

5 This statement is taken from Mečkovskaja's presentation in 2007 at University of Tübingen "Jazykovaja situacija v Belarusi: tipy individual'nogo dvujazyčija i fenomen trasjanki". Translation into English: N.S.
} 
the Belarusian linguist Zaprudski argues that Trasianka was substantially used for the first time only in connection with intensive urbanization between the 1960s and 1970s. ${ }^{6}$

Indeed, this time frame seems to be of very decisive importance for an increased spread of the Trasianka due to the then-intensified contact between the mainly Belarusian speaking rural population $^{7}$ and the newly immigrated Russian-speaking Soviet elites in the cities. ${ }^{8}$ This viewpoint is confirmed by Hentschel (2008b: 174). He argues that Trasianka as a mass phenomenon only occurred after the Second World War due to urbanization, industrialization and migration from the countryside to the cities. On the basis of current research, a two-step development in the usage of Trasianka is most likely. The first step was the process of Russification in Belarus, which led to a first level of language mixing - probably affecting only a limited number of residents working in professions at the hinge between Russianspeaking immigrants and Belarusian-speaking natives, e. g., in the areas of administration, security, and trade. The second step probably was caused by the Second World War and the Sovietification. This level is characterized by massive changes in social structure and socioeconomic properties of the people in Belarus. During the war, almost one third of the Belarusian inhabitants died. Afterwards, thousands of Belarusian speakers moved from the villages to the cities, worked in newly established companies and attended universities where Russian was the dominant language because it was the lingua franca of the USSR. It also became the language of the elites in Belarus because thousands of native Russian-speaking workers, experts and intelligentsia now moved to Belarus. It was this mass migration and newly established language contact that seem to mark the breakthrough of Trasianka. However, this two-step follow-up is as yet more an assumption than an explanation. It urgently needs to be verified through further research.

\section{$3 \quad$ Trasianka in linguistic research}

It is not only the point in time and the processes of the emergence of Trasianka that are still the subject of research: today, even the term Trasianka is often inconsistently used in research. In English-speaking literature Trasianka is sometimes written <trasjanka> (cf. Nekvapil 2007: 146), <trasianka> (cf. Brown 2005: 316), <transyanka> (cf. Ioffe 2003: 1014), <trashanka> (cf. Koshino 2005: 179) or <trasyanka> (cf. Ioffe 2003: 1015). Some people even use totally different labels for this variety. In everyday life in Belarus, the expressions smešannyj jazyk ('mixed language'), trassa ('mixture'), jazyk na kotorom vse razgovarivajut ('a language everybody uses'), kolchoznyj jazyk ('language of the kolkoz') or bazarnyj jazyk ('marketplace language') are also popular to describe what I name Trasianka here.

Another challenge is the fact that it is still under discussion what researchers in sociolinguistics exactly mean when they use the term Trasianka. Mečkovskaja for instance defines Trasianka as a "variety of idiolects (meaning individual language, individual language systems), which contain traits of Belarusian and Russian in a different amount". ${ }^{9}$ In an earlier work Mečkovskaja (1994: 313, translation: N.S.) stated, that "Trasianka is compounded by a

\footnotetext{
${ }^{6}$ This statement is taken from the lecture "Trasjanka', 'dvujazyčie', kody, 'nizkie' i 'vysokie' jazyki...", which was given by Zaprudski during a conference (Trasjanka and Surzhyk. Products of Byelorussian-Russian and Ukrainian-Russian language contact) at University of Oldenburg in 2007. Translation into English: N.S.

7 This is an assumption. It is unclear to which extent the rural population of this time really spoke standard Belarusian or to which extent they used dialects, Trasianka, Russian or something else. This question needs to be further examined.

${ }^{8}$ Compare the data on the shifts of the population structure of Minsk since the end of the Second World War: Bohn (2008: 151-154).

9 This definition is taken from Mečkovskaja's presentation in 2007 at University of Tübingen "Jazykovaja situacija w Belarusi: tipy individual'nogo dvujazyčija i fenomen trasjanki". Translation into English: N.S.
} 
diversity of spontaneous and in a different way russified individual variants of Belarusian". Liskovec (2006: 66) considers Trasianka an imperfectly learned Russian by speakers from Belarus, Cychun (2000) sees Trasianka as a creolized variant of Belarusian.

This variety of standpoints reflects not only different historical viewpoints, but also confirms Hentschel's view (2008b: 169) that current identifications of Trasianka are not definitions in a narrow sense, but more of an undertaking to describe Trasianka as a phenomenon. From my perspective based on current research, there is good reason for the interpretation that Trasianka can be considered a language mixing, but I also believe that further studies need to be carried out. Inter alia, the questions must be answered if it consists of regular patterns (cf. Grenoble 2010: 591), and whether Trasianka indeed can be considered a mixed language (cf. Hentschel 2008a: 455).

\section{$4 \quad$ Taking the sociolinguistic perspective}

It seems to be the case that almost everybody in contemporary Belarus is able to recognize the mixed language between Russian und Belarusian - may he or she call it Trasianka or something else. So research on language attitudes can begin even without further results on definitions and explanations on language development. From the perspective of research on language attitudes, the question arises how speakers of Trasianka are recognized in society and which social judgments are connected with this variety. To address this question, one first needs to determine who speaks Trasianka when, where and why today.

Along with research on grammar sociolinguistic studies on Trasianka have also only just begun. Liskovec (2006) offers at least one empirical study with a sociolinguistic approach. Her 1999-2002 study used a qualitative approach by interviewing a rather low number of people in Minsk. One result of Liskovec' research is that about 30-35 percent of Minsk's residents speak Trasianka. Additionally, Liskovec reasoned that speakers of Trasianka were born on the countryside and only relocated to the capital during their lifetime (cf. id. 2006: 105). She eventually concluded that Trasianka is viewed as a low estimated variety in comparison with Belarusian and Russian - both from the perspective of its own speakers as from the perspective of other residents (cf. id. 2006: 102, 168).

Because of her relatively low number of test participants my own intention of study was to test Liskovec' results and to engage in deeper research on language attitudes. I asked the following questions: What language attitudes are predominant among Belarusian residents towards speakers of Trasianka? And are there certain shared negative attitudes connected with speakers of Trasianka?

\section{$5 \quad$ Measuring language attitudes towards speakers of Trasianka}

In general, there is consensus among researchers that language attitudes are actually social attitudes - specifically attitudes towards certain groups of speakers. Thus it is not the language itself that is rated (cf. Casper 2002: 57). Following this argumentation, my study measured attitudes of test participants towards speakers of Trasianka by determining ratings of key properties of Trasianka speakers. Up- or downgrading of Trasianka speakers compared to speakers of Russian or Belarusian could be taken as evidence for the existence of certain language attitudes. Building on earlier works (cf. Liskovec 2006; Labov 1966) I expected lower ratings for Trasianka-speakers in matters of socio-demographic properties (e. g., profession, education), traits of competence (e. g., language competence) and social distance (e. g., desirability as a neighbor). So I drafted the following starting hypothesis: Residents of Belarus assume that speakers of Trasianka work in jobs with fewer qualifications (H1), have only finished a relatively low-level education (H2), have relatively little knowledge of foreign languages (H3), and they vote their personal traits low (H4). 
I decided to test these four hypotheses by using standardized interviews and an adopted matched-guise technique. During the interviews, the participants listened to recorded text passages. The text, about 15 sentences long, was read by a female. She read the very same text translated into Russian, Belarusian and Trasianka. ${ }^{10}$ It contained a description of an everyday life situation (non-prose). ${ }^{11}$ All participants had to listen to those recordings in the very same order (see Table 1). The total amount of time to listen to the recordings and to answer the questionnaire was about 30 minutes for each participant. I led all interviews, sometimes with only one participant and the recordings in front of me, sometimes with up to 30 in a group, added up to 227 interviews.

\begin{tabular}{|c|c|}
\hline & Briefing by interviewer and circulation of questionnaires \\
\hline \multirow[t]{2}{*}{$1^{\text {st }}$ recording } & $\begin{array}{l}\text { Playback of text in Russian by a female speaker for familiarization of } \\
\text { participants with conditions of recordings and questionnaire (without } \\
\text { analysis and for cloaking purpose only) }\end{array}$ \\
\hline & Completion of $1^{\text {st }}$ questionnaire by participant(s) \\
\hline \multirow[t]{2}{*}{$2^{\text {nd }}$ recording } & $\begin{array}{l}\text { Playback of text in Belarusian by the same female speaker (for } \\
\text { analysis) }\end{array}$ \\
\hline & Completion of $2^{\text {nd }}$ questionnaire by participant(s) \\
\hline \multirow[t]{2}{*}{$3^{\text {rd }}$ recording } & $\begin{array}{l}\text { Playback of text in Trasianka by a female speaker (for cloaking and } \\
\text { referencing) }\end{array}$ \\
\hline & Completion of $3^{\text {rd }}$ questionnaire by participant(s) \\
\hline \multirow[t]{2}{*}{$4^{\text {th }}$ recording } & $\begin{array}{l}\text { Playback of text in Russian by a female speaker (for cloaking and } \\
\text { referencing) }\end{array}$ \\
\hline & Completion of $4^{\text {th }}$ questionnaire by participant(s) \\
\hline \multirow[t]{2}{*}{$5^{\text {th }}$ recording } & $\begin{array}{l}\text { Playback of text in Trasianka by the same female speaker (for } \\
\text { analysis) }\end{array}$ \\
\hline & Completion of $5^{\text {th }}$ questionnaire by participant(s) \\
\hline \multirow[t]{2}{*}{$6^{\text {th }}$ recording } & $\begin{array}{l}\text { Playback of text in Belarusian by a female speaker (for cloaking and } \\
\text { referencing) }\end{array}$ \\
\hline & Completion of $6^{\text {th }}$ questionnaire by participant(s) \\
\hline \multirow[t]{4}{*}{$7^{\text {th }}$ recording } & $\begin{array}{l}\text { Playback of text in Russian by the same female speaker (for } \\
\text { analysis) }\end{array}$ \\
\hline & Completion of $7^{\text {th }}$ questionnaire by participant(s) \\
\hline & $\begin{array}{l}\text { Completion on statistical data on participants in separate part of the } \\
\text { questionnaire }\end{array}$ \\
\hline & Collection of questionnaires and debriefing by interviewer \\
\hline
\end{tabular}

Table 1: Order of recordings during the interviews

After listening to each text in one variety, all participants were asked to fill out a standardized questionnaire. In sum, they were asked to answer seven blocks of questions in four categories for each speaker. The first category consisted of questions on probable and improbable professions of the speakers, on their regional origin and their education (socio-demographic questions and traits of competence). The second category of questions aimed at social distance (e. g., whether the test participants would collect strawberries with the speaker or

10 I decided to use a very strong synthetic Trasianka in the study to make it easier for the participants to recognize this language as something different from Russian and Belarusian. This strong Trasianka contains approximately the same contingent of standard Russian and Belarusian elements. My personal knowledge in all three varieties helped me draft the non-prose text and compare and adjust the recordings of this text in all three varieties with my original draft.

11 The duration of the recorded speech in all three languages differed only a bit, and amounted in the end to one minute. 
would like to accept them as a neighbor). The third section consisted of questions on positive and negative characteristics. In total, the participants were asked to answer questions on 23 items with multiple answers possible on several questions. First, I decided to use a set of questions on personal traits designed as five-point semantic differential scales. Second, I designed a set of questions for ordinal rankings on items like profession, education, and birthplace. In the following, I present only the preliminary results on ordinal aspects.

For the determination of existing attitudes, I designed a two-level benchmark. On the level of language, I not only asked for ratings on traits of speakers of Trasianka, but also on traits of speakers of Russian and Belarusian. So the same text was spoken in Trasianka, Russian and Belarusian. Having isolated the variety, the next logical step was to isolate the speaker. So I decided on the second level to have read the texts in all three varieties by one person - and use other persons for cloaking purposes only (see Table 1). In the following, I ignore these three additional persons for cloaking and concentrate on the analysis of the one person speaking in Russian, Belarusian and Trasianka as well.

Following the matched-guise technique, language attitudes were therefore not directly evaluated by asking whether or not speakers of Trasianka work in high-profile or low-profile jobs in the opinion of the participants. My method was to instead gather reactions by the residents on a voice they had just listened to. So after each listening session, the test participants had to choose one or more assumed professions of the female speaker from a given list of jobs. This list contained a number of different professions covering a range of jobs requiring a high qualification, and others that do not. I assume an existing correlation between a necessary high qualification of a job and a resulting high prestige of this job. So the participants had to choose one or more of the most likely/most unlikely professions from this list to describe the female speakers they had just listened to. These ratings consequently show a ranking of probable professions of one person using the different varieties Trasianka, Russian and Belarusian. Beyond professions, this was repeated in the same way for the other variables.

\section{$6 \quad$ Preliminary results}

In the following, I present the initial results of my research based on the answers of 227 participants collected by me from the end of January to mid-February 2009 in the capital of Belarus, Minsk. ${ }^{12}$ I thereby only concentrate on the items regarding assumed professions, education, knowledge of foreign languages and desirability as a neighbor by my interlocutors.

For evaluating the opinions on jobs of the speaker using different varieties, the participants received a list of professions covering a wide range, from jobs requiring a rather low qualification in Belarus (salesperson, painter, assembly line worker, cleaner) to jobs requiring higher qualification (lawyer, physician, teacher, secretary). ${ }^{13}$ From this list, the participants chose one or more as the most probable job(s). The answers to this item show that the participants assumed very different possible jobs depending on the variety the person used while reading her text. When she used Trasianka, the majority of the 227 participants assumed that her profession would more likely be in a job requiring low qualification (see Figure 1).

\footnotetext{
12 In the second cohort, an additional 63 persons were interviewed in the following year. The data of both cohorts will be analyzed in my doctoral thesis to be published soon.

13 I only use these two categories at this point of the study; a more differentiated scale will be used in further research. For this, I asked 63 participants to rank the reputation of the jobs used here. They ordered as follows (from the highest score 1 to the lowest 8): (1) lawyer $(M=1,76),(2)$ physician $(M=2,21)$, (3) teacher $(M=$ $3,37)$, (4) secretary $(M=3,99),(5)$ salesperson $(M=5,44),(6)$ painter $(M=5,87),(7)$ assembly line worker $(M=$ $6,03)$, (8) cleaner $(M=7,27)$. So these two categories mark not only two levels of qualification, but also two distinctly separated levels of reputation, with an obviously clear-cut distinction between the upper half (including secretary) and the lower half (starting with salesperson).
} 
With multiple answers possible, 125 participants (55\%) said that it was more likely that the female speaker worked as a salesperson, $115(51 \%)$ assumed that she worked as a painter, 111 (49\%) saw her working as an assembly line worker and $97(43 \%)$ thought that she worked as a cleaner. Hence, the clear majority saw the speaker using Trasianka to be working in the jobs requiring the least education. ${ }^{14}$ As the speaker used Russian and Belarusian, however, the participants rated inversely. In this circumstance, only a minority of 3 percent of the participants assumed that the speaker worked as a cleaner when using Russian, 15 (7\%) saw her possibly working as a painter in this case, and 17 (7\%) as an assembly line worker. The majority of participants thought instead that it would be more likely that this Russian speaker worked as a secretary ${ }^{15}(58 \%)$, as a physician $(40 \%)$ or as a teacher $(34 \%)$. Since all but one conditions of the experiment remained stable, the differences in the participants' judgments can only be explained by the single changed variable: the language the speaker used to read the identical text. These figures give good arguments for the conclusion that the residents of Belarus classify Trasianka-speaking people to have professions with few qualifications, whereas they place speakers of Russian and Belarusian in work requiring higher qualifications.

To test the reliability of this result, I added an additional opposing question: I also asked during the interviews what profession the speaker would most likely not have in the participants' opinion. The answers to this question confirm the results of the question on the most-likely jobs, as they form a clear mirror image to these answers (see Figure 2). When asked about the less-likely professions, a remarkable number of 178 (78\%) test persons answered that the speaker using Trasianka most likely did not work as a lawyer in their opinion and $142(63 \%)$ said that she most likely not worked as a teacher. On the other side only 7 test persons $(3 \%)$ said that it was unlikely that the very same female speaker using Trasianka worked as a salesperson, $10(6 \%)$ said it was unlikely that the Trasianka speaker worked as a cleaner and $14(6 \%)$ said it was unlikely in their opinion that the woman worked as an assembly line worker. When speaking Belarusian or Russian, however, the most unlikely jobs were seen in the low qualification area. With this data from both questions regarding the professions I confirm my initial hypothesis H1. Indeed, speakers of Trasianka are downgraded in the matter of likely professions - there is a negative language attitude performed in other words.

\footnotetext{
${ }^{14}$ See footnote 13 .

${ }^{15}$ In Belarus this kind of job is seen much more than in other countries situated in the high-qualification area (see footnote 13).
} 


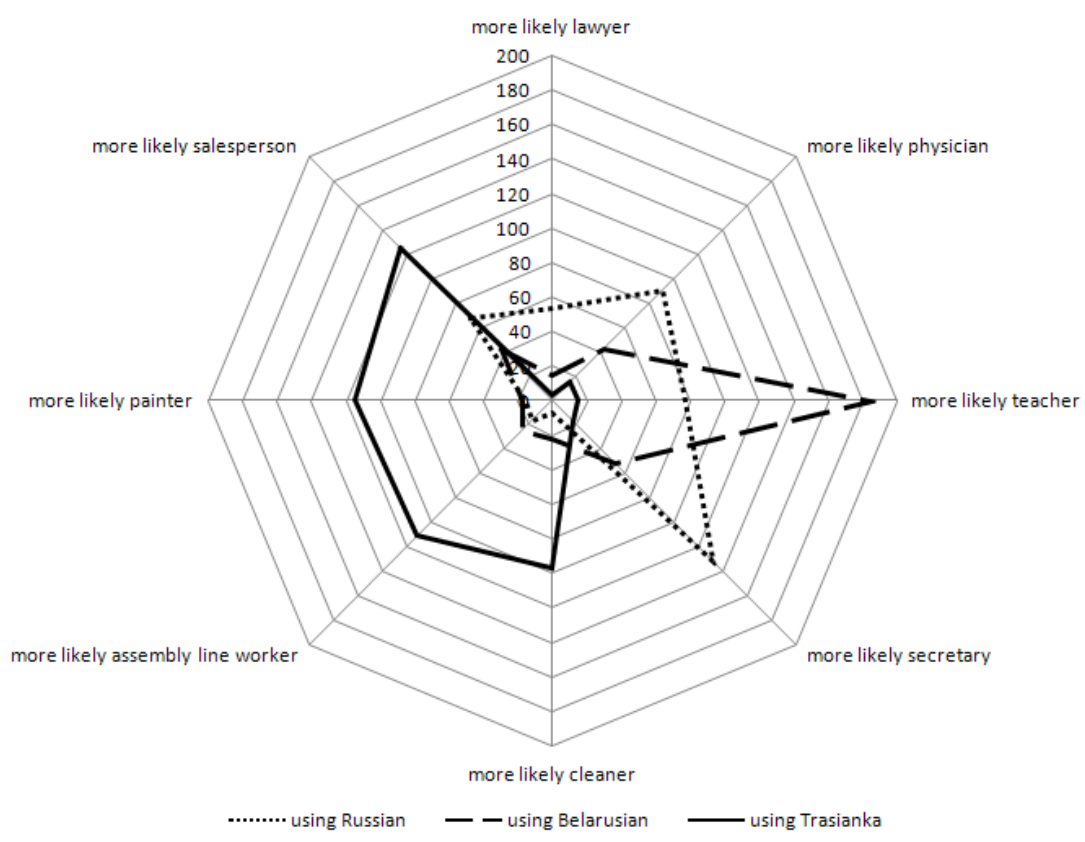

Figure 1: Assumed professions depending on the languages used by the only one speaker ${ }^{16}$

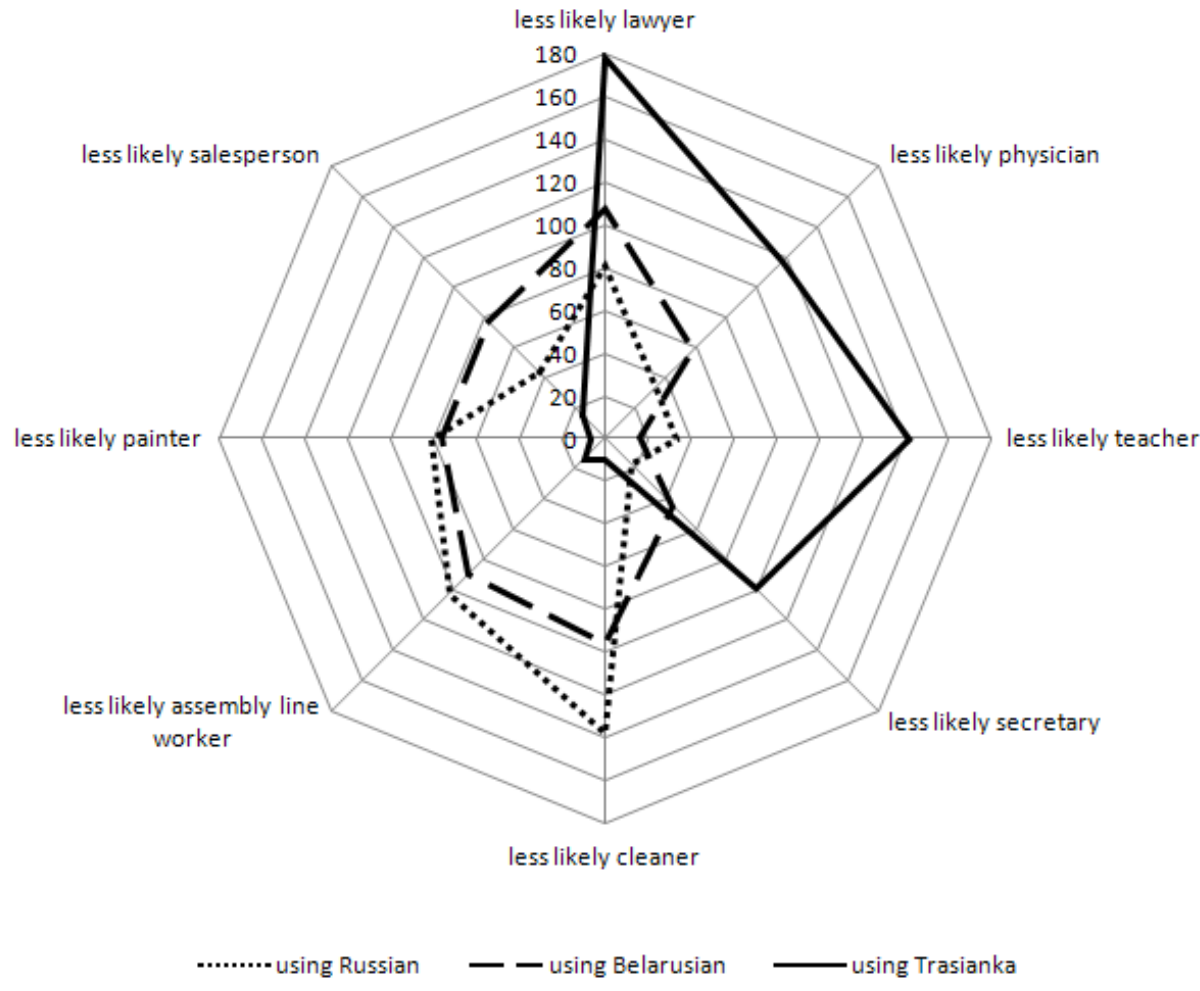

Figure 2: Unlikely professions depending on the languages used by the only one speaker ${ }^{17}$

\footnotetext{
16 Survey among N=227 inhabitants of Belarus between January and February 2009 in Minsk. Displayed is the number of affirmative answers to 8 professions on the question: "Кем могла бы эта женщина работать?" ('What could be the profession of this woman?'). Multiple answers were possible.

${ }^{17}$ Survey among N=227 inhabitants of Belarus between January and February 2009 in Minsk. Displayed is the number of affirmative answers to 8 professions on the question: "Кем эта женщина вряд ли работает?" ('What is unlikely that this woman could work?'). Multiple answers were possible.
} 
In connection to the question on professions, the participants were asked to rate the assumed highest education of the speaker. After each listening session, I asked the participants to select from a list of educational levels ranging from the lowest (more likely 9-class school ${ }^{18}$ ) to the highest (more likely university). Depending on the language used by the only one speaker, the participants rated differently again under stable conditions of text and interview situation. As long as the speaker used Russian or Belarusian, practically none of the participants evaluated her to have absolved only the 9-class school or 11-class school (see Figure 3). Instead, 143 participants $(63 \%)$ expected that the speaker had attended university when she used the Belarusian language. Using Russian, it was 137 (60\%). When using Trasianka, however, the speaker was rated as a person who had only finished a lower education much more often. With 9 (4\%) affirmative answers, only a clear minority of the participants opined that the Trasianka speaker could be a graduate of a university. This stands in sharp contrast to the ratings by the participants when the female speaker used Belarusian or Russian for her text. Thus, the conclusion can be drawn that the female speaker was again differently rated depending on the language she had used. So there is good reason to verify hypothesis H2: in Belarus the majority of the people believe that speakers of Trasianka have only absolved a low-level education.

Specific attitudes towards speakers of Trasianka can also be found in areas beyond social demographics. When answering the competency-oriented question whether the speaker was proficient in foreign languages, the participants most frequently answered "yes" and "more likely yes" when the speaker used the Russian language or the Belarusian language for reading her text (see Figure 4). 68 percent of the participants voted that way for Belarusian, 60 percent for Russian. When the female spoke Trasianka, however, only 8 percent of the participants had the impression that she was competent in foreign languages. Most of the answers (92\%) were "more likely no" or "no" when the speaker used Trasianka. Similar to the questions on profession, all basic conditions of the interview remained stable. So the conclusion is justified that speakers of Trasianka, only by using their language, are downgraded in matters of competence as indicated here by the aspect of foreign language competency. So the verification of my initial hypotheses H3 is confirmed: There are negative attitudes existing among citizens of Belarus whereby speakers of Trasianka are perceived to have low competencies in foreign languages - an attribute of personal competence. ${ }^{19}$

\footnotetext{
18 '9-class school' is a translation for better international understanding. The item was named базовое образование in the questionnaire.

19 Of course the variables "foreign language competencies" and "education" are correlative. The assessment of speakers of Trasianka as having not completed a university education explains the judgment of the participants that those speakers more likely do not have foreign language competencies.
} 


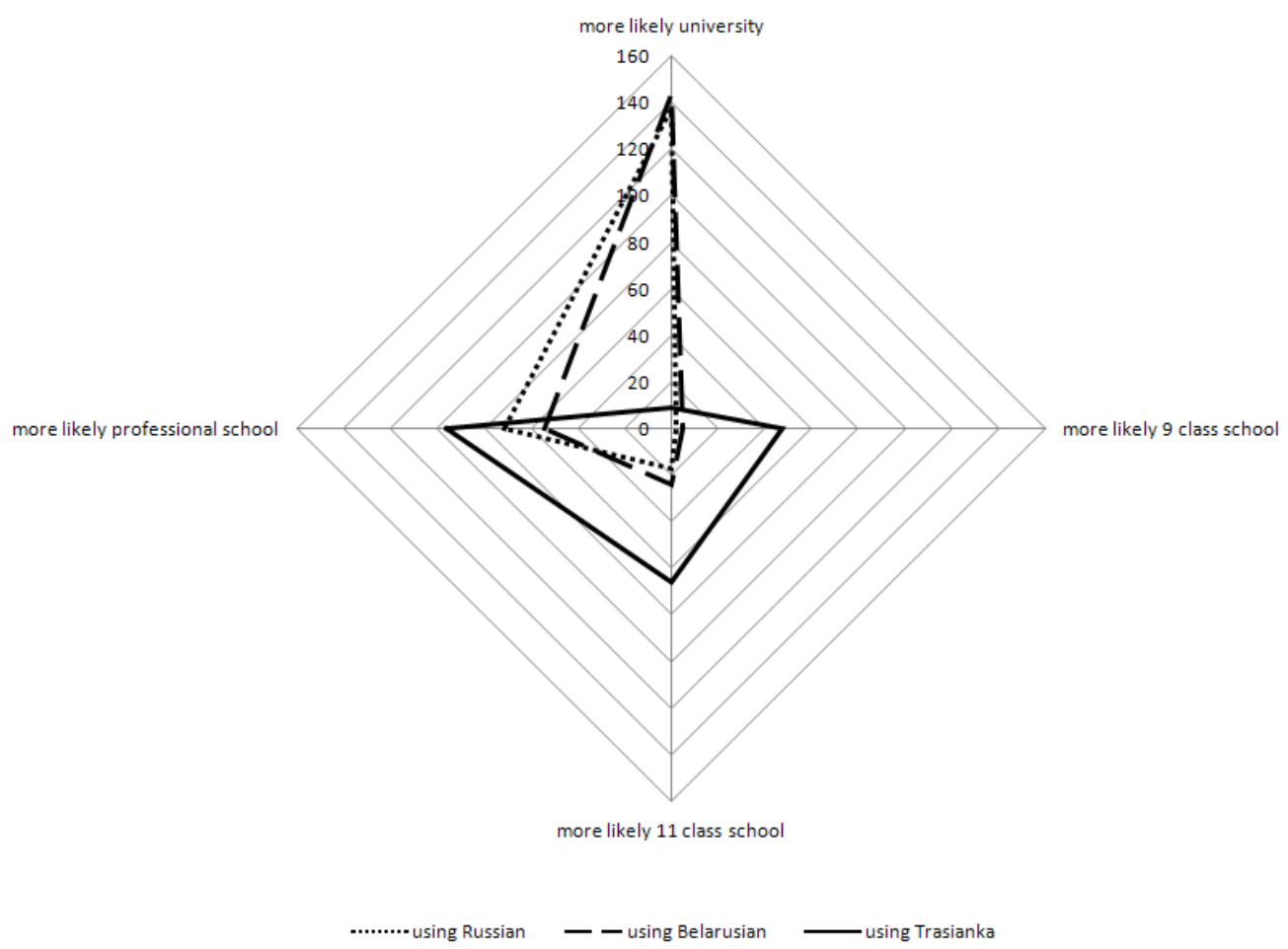

Figure 3: Assumed level of education depending on the languages used by the only one speaker ${ }^{20}$

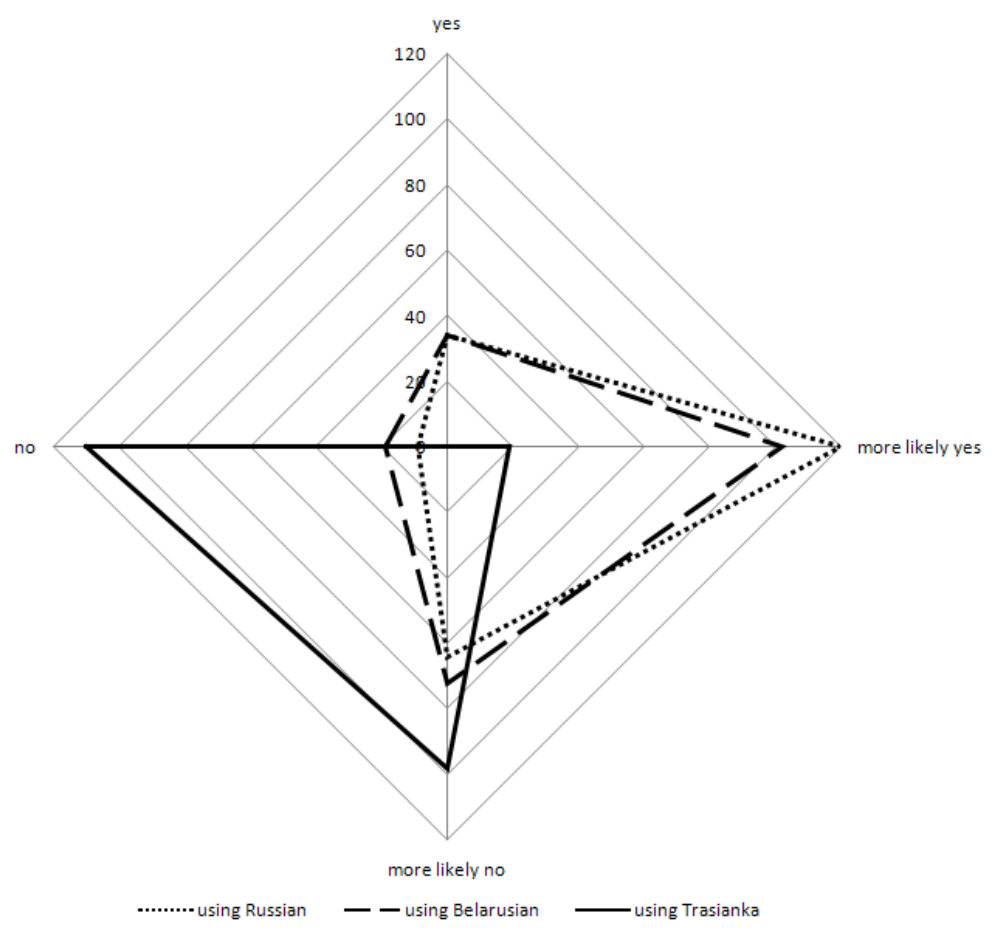

Figure 4: Assumed knowledge of foreign languages depending on the languages used by the only one speaker ${ }^{21}$

\footnotetext{
20 Survey among N=227 inhabitants of Belarus between January and February 2009 in Minsk. Displayed is the number of affirmative answers to the question: "Какое у этой женщины могло бы быть наивысшее образование?" ('What is the highest level of education this woman has completed?'). "9-class school", "11-class school" and "professional school" are translations for better international understanding. The item 9-class school was named базовое образование, the item 11-class school среднее образование and professional school среднее профессиональное образование in the questionnaire.
} 
In order to get an impression of the assumed personal traits, the participants were asked during the interview whether they would welcome the speaker as their neighbor. I assume here that this item can serve as an indicator for social distance. For the participants, four potential answers were offered ("yes", "more likely yes", "more likely no" and "no"22), from which they were asked to choose one. Again, the participants showed a responsiveness which marks a differentiation depending on the languages used by the very same speaker. Practically none of the participants answered with an unconditional "yes" to the question whether they would like to have the Trasianka speaker as a neighbor (see Figure 5). On the other side, fewer of the participants rejected the woman as a neighbor when she read the very same text in Russian or Belarusian. This response marks a substantial difference in the popularity of Trasianka speakers. With this data, my initial hypotheses $\mathrm{H} 4$ can be verified: speakers of Trasianka have a lower popularity than speakers of Russian and Belarusian. Furthermore, my analysis gives good evidence that this downgrading is not connected with the language or social status of the participants. It was not only participants who spoke the Russian or Belarusian language that downgraded speakers of Trasianka - Trasianka-speakers also rated themselves this way.

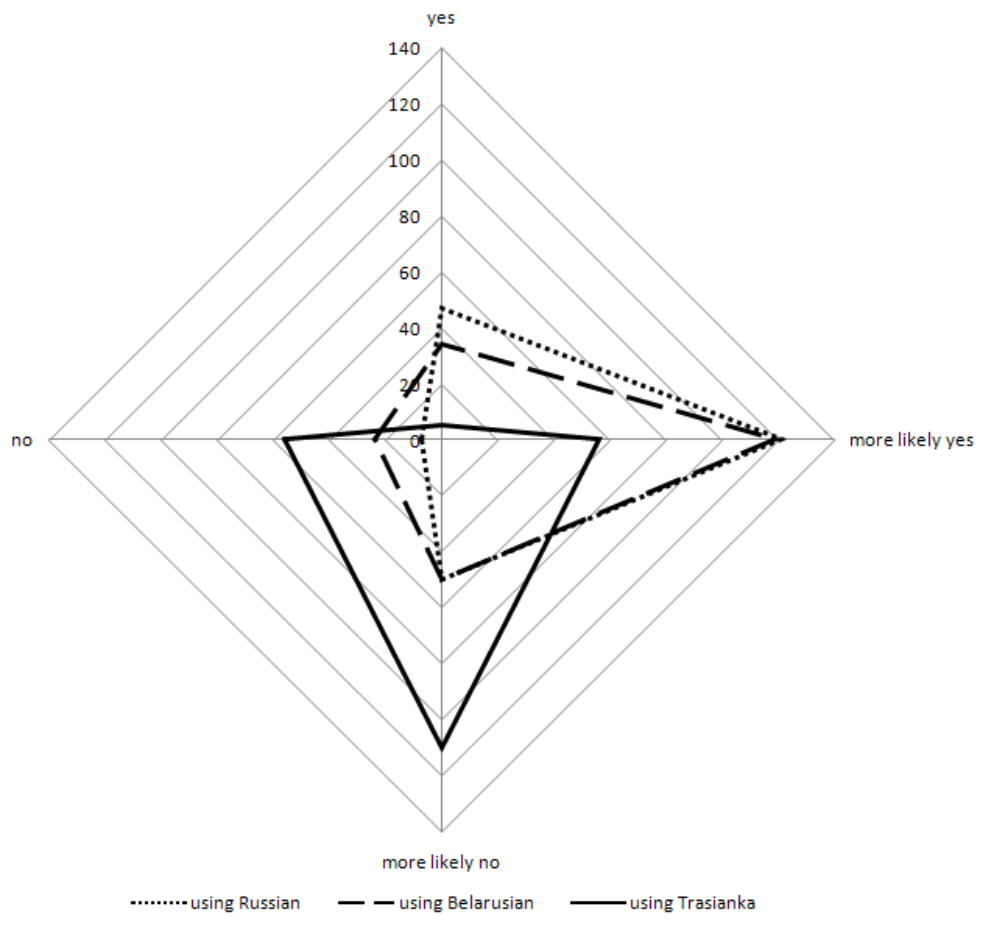

Figure 5: Desirability as a neighbor depending on the languages used by the only one speaker ${ }^{23}$

\footnotetext{
21 Survey among N=227 inhabitants of Belarus between January and February 2009 in Minsk. Displayed is the number of affirmative answers to the question: "Владеет ли эта женщина, по Вашему мнению, иностранными языками? (не русским/белорусским языками)" ('Is this female in your opinion able to speak foreign languages [not Russian/Belarusian]?').

22 In Russian: "да", "скореe да", "скорее нет", "нет".

23 Displayed is the number of affirmative answers. Multiple answers were possible. Survey among N=227 inhabitants of Belarus between January and February 2009 in Minsk. Question: "Хотели бы Вы иметь такую соседку?" Translation: 'Would you wish this woman as your neighbor?'
} 


\section{Conclusion: language attitudes towards speakers of Trasianka}

Which main conclusions can be drawn from these first results of the survey? First and foremost: As long as the female speaker used Trasianka, she was rated remarkably differently. On each single item, the participants rated less positively when the speaker used Trasianka. The participants rated her lower in matters of socio-structural issues such as profession and education. The participants also assumed that the Trasianka speaker was less qualified - as shown in the answers to the question regarding competencies in foreign languages. Finally, the participants were more reluctant to accept the Trasianka speaker as a neighbor. With this response, they showed a clear downgrading in social distance. In sum, the speaker of Trasianka was considerably downgraded on all four items - in contrast to the situation when the very same female read the text in Belarusian and Russian. Since all general conditions in the survey remained stable, with the sole exception of the language used, there is evidence to conclude that the inhabitants of Belarus rate speakers of Russian, Belarusian and Trasianka in general in a different way. These findings suggest the preliminary conclusion that negative attitudes are present regarding those aspects - and they are uniquely connected with the language used.

The next step of my studies will be to verify this conclusion by analyzing more cases and the ratings on semantic differential scales for which data has already been allocated. Furthermore, it still remains to be seen if speakers of Trasianka really hold opinions that correspond with those negative ratings. Compared to the impartial properties of speakers of Trasianka, the observed judgments could be exaggerated or even wrong. Not each and every speaker of Trasianka must possess a rather low-level school education, and there could be many more speakers of Trasianka who possess a university degree than expected by the participants. The same needs to be clarified regarding profession, competencies on foreign languages and the other variables. Together with the remaining 63 participants of the second cohort, and with additional interviews with about 30 speakers of Trasianka this study will further elaborate on those issues with final results to be published soon.

\section{References}

Bohn, Thomas M. (2008): Minsk, Musterstadt des Sozialismus. Stadtplanung und Urbanisierung in der Sowjetunion nach 1945. Cologne: Böhlau.

Brown, N. Anthony (2005): "Language and identity in Belarus". Language Policy 4: 311332.

Casper, Klaudia (2002): Spracheinstellungen. Theorie und Messung. Heidelberg.

Cychun, Genadz' (2000): "Krealizavany pradukt. Trasjanka jak ab'ekt lingvistyčnaga dasledavannja". http://pdf.kamunikat.org/13924-1.pdf, accessed February 9, 2014.

Dunin-Marcinkevič, Vicent (2001): "Pinskaja šljahta". In: Vybranyja tvory. Minsk., Mastackaja litaratura: 53-72.

Grenoble, Leonore N. (2010): "Contact and development of the Slavic languages". In: Hickey, Raymond (ed.): The handbook of language contact. Malden, MA: WileyBlackwell: 581-597.

Hentschel, Gerd (2008a): "Einige Beobachtungen zur Flexionsmorphologie in der Trasjanka. Zur Variation zwischen weißrussischen und russischen Endungen und Formen beim Verb, Adjektiv und anaphorischen Pronomen". In: Nagórko, Alicja/Heyl, Sonja/Graf, Elena (eds.): Sprache und Gesellschaft. Frankfurt a. M., Lang: 454-466.

Hentschel, Gerd (2008b): "Zur weißrussisch-russischen Hybridität in der weißrussischen 'Trasjanka"'. In: Kosta, Peter/Weiß, Daniel (eds.): Slavistische Linguistik 2006/2007. Referate des XXXII. und XXXIII. Konstanzer Slavistischen Arbeitstreffens. Munich, Sagner: 169-219. 
Ioffe, Grigory (2003): "Understanding Belarus. Questions of language". Europe-Asia Studies 55/7: 1009-1047.

Koshino, Go (2005): "The representation of the Belarusian language in contempory Belarusian literature". In: Matsuzato, Kimitaka (ed.): Emerging meso-areas in the former socialist countries. Histories revived or improvised? Sapporo, Hokkaido University: 177191. (= Slavic Eurasien studies 7).

Kupala, Janka (2006): Tutejšyja. Minsk: Mastackaja litaratura.

Labov, William (1966): The social stratification of English in New York City. Washington: Center for Applied Linguistics.

Liskovec, Irina (2006): Russkij $i$ belorusskij jazyki v Minske: Problemy bilingvizma $i$ otnošenija k jazyku. European University St. Petersburg. Unpublished dissertation.

Mečkovskaja, Nina Borisovna (2007): "Jazykovaja situacija w Belarusi: Tipy individual'nogo dvujazyčija i fenomen trasjanki". University of Tübingen. Presentation.

Mečkovskaja, Nina Borisovna (1994): "Jazykovaja situacija w Belarusi: Etičeskie kollizii dvujazyčija". Russian Linguistics 18: 299-322.

Nekvapil, Juři (2007): "On the relationship between small and large Slavic languages". International Journal of the Sociology of Language 183: 141-160.

Narodnaja Volja, (2001): https://web.archive.org/web/20081120163307/http://tbm.org.by/ tbm_old/bel/mova/2001/11.htm, accessed February 6, 2014.

Radio Stalitsa. http://www.tvr.by/liveair/radiostol.asx, accessed February 6, 2014.

Sender, Natallia (2008): Spracheinstellungen zur weißrussisch-russischen Mischsprache Trasjanka in Belarus. Europa-Universität Viadrina, Frankfurt/Oder. Unpublished master thesis.

Zaprudski, Sergej (2007): "Trasjanka', 'dvujazyčie', kody, 'nizkie' i 'vysokie' jazyki..." University of Oldenburg. Lecture. 